\title{
Towards the development of self-compacting no-slump concrete mixtures
} His field of interest is rheology of paste, mortar, concrete and granular material. He is RILEM member and (co-author of about 20 conference and journal papers. He was a lecturer and research associate in American Concrete Institute (ACl), Iran Chapter.

Hooman HOORNAHAD - Microlab, Faculty of Civil Engineering and Geosciences, Delft University of Technology - h.hoornahad@gmail.com

EduARDus A. B. KOENDERS - Institute for Construction and Building Materials, Technische Universität Darmstadt • koenders@wib.tu-darmstadt.de

KLAAS VAN BREUGEL - Microlab, Faculty of Civil Engineering and Geosciences, Delft University of Technology • k.vanbreugel@tudelft.nl

Érkezett: 2015. 07. 31. - Received: 31. 07. 2015. - http://dx.doi.org/10.14382/epitoanyag-jsbcm.2015.22

\section{Abstract}

No-slump concrete (NSLC) and self-compacting concrete (SCC) are two types of concretes, which became increasingly adapted by the concrete industry because of their specific rheological characteristics. For NSLC mixtures the high shape holding ability allows formworks to be removed shortly after concrete placing. However, NSLC needs a large amount of energy to be properly compacted. For SCC mixtures it is the high flowability and self-compactability that makes them unique. However, as SCC is not able to preserve its shape right after placing, formwork cannot be removed directly after casting. By comparing these two extreme cases, an ideal mixture would have been obtained, i.e. a self-compacting no-slump concrete (SCNSLC), which can compact under its own weight and maintains its shape right after casting. In this paper the possibility of a self-compacting no-slump concrete (SCNSLC) is discussed. The rheological behaviour of these mixtures in the dormant period is in focus, when the degree of hydration is still very limited. The shape holding ability of both mixtures is characterized by a shape preservation factor $0<\mathrm{SPF} \leq 1$. SPF shows the ability of a mixture to preserve its shape after lifting the cone during a slump test. SPF is the ratio of the vertical cross sectional area of a sample after and before lifting the cone. By increasing flowability of a mixture, the SPF decreases. Results show how to design such mixtures having optimized rheological properties between those of NSLC and SCC.

Keywords: Rheological behaviour, self-compacting no-slump concrete, two-phase aggregate-paste model, shape preservation factor

Kulcsszavak: Reológiai viselkedés, roskadásmentes öntömörödó beton, kétfázisú adalékanyagpép modell, alaktényezó

\section{Introduction}

Fresh concrete is a material with continuously changing properties [1]. Concrete gradually changes from a workable mixture into an artificial stone as a result of the hydration process. With respect to the degree of hydration, the period after mixing can be divided into three main periods [2]:

The dormant stage, representing the time interval when the degree of hydration is still very limited and does not significantly affect the rheological behaviour of concretes.

The setting period, representing the time interval in which the development of the degree of hydration leads to a gradual transition of fresh concrete to a solid.

The hardening period, representing the time interval in which concrete gradually gains strength.

Concrete mixtures vary between two extremes with respect to the early age rheological behaviour: no-slump concrete (NSLC) and self-compacting concrete (SCC) [3].

A NSLC mixture has almost zero flowability [4]. A NSLC mixture is able to preserve its shape right after placing. Slip forming method can be used for construction [5]. However, a no-slump concrete is basically a low cement paste mixture that needs a large amount of energy for a proper compaction $[4,5]$.

A SCC mixture has high flowability. The high flowability is usually achieved by reducing the aggregate content and increasing the paste content with excellent deformability [6].
The deformability can be adjusted by incorporating fillers and admixtures. A SCC mixture is able to compact under its own weight, without applying any external compaction energy [3, 6]. However, as it is not able to preserve its shape right after placing, formwork cannot be removed shortly after placing [5].

By comparing NSLC and SCC, it can be concluded that a very efficient mixture from rheological perspective would be the one which behaves like SCC during casting and behaves like NSLC right after placing. The objective of this paper is to study the possibility of developing such a self-compacting no-slump concrete (SCNSLC), i.e. a self-compacting mixture which can preserve its shape completely right after casting.

\section{Rheological model}

Fresh concrete is considered as a discontinuous system in this study and it is represented by a two-phase model [7]. These phases are aggregate and paste (see Fig. 1.a). The paste consists of powder particles dispersed in water. $0.125 \mathrm{~mm}$ is considered for the boundary size between the aggregate and powder particles [8].

The granular phase is characterized by a factor $\boldsymbol{s}$, i.e. the packing density of the aggregate. $\boldsymbol{\varsigma}$ is expressed as follows:

$\varsigma=\frac{\mathrm{V}_{\mathrm{a}}}{\mathrm{V}_{\mathrm{b}}} \leq 1$ 
$\mathrm{V}_{\mathrm{a}}$ is the specific (solid) volume of aggregate and $\mathrm{V}_{\mathrm{b}}$ is the bulk volume of aggregate which represents an aggregate skeleton in a compacted state (see Fig. 1.b). The packing density of aggregate depends on the particle size distribution, shape characteristics of the aggregate particles and packing method [9]. Hu and de Larrard [10] proposed the following expression for the maximum packing density of aggregate with a broad particle size distribution:

$\zeta_{\max }=1-0.45\left(\frac{D_{\min }}{D_{\max }}\right)^{0.19}$

where $\mathrm{D}_{\min }$ and $\mathrm{D}_{\max }$ are the diameters of the smallest and the largest aggregate particles in the granular skeleton, respectively. In a system of multiple sizes of aggregate, smaller aggregate particles fill up the gaps between the larger aggregate particles and lead to a smaller void volume of the granular skeleton and thus higher packing density [9].
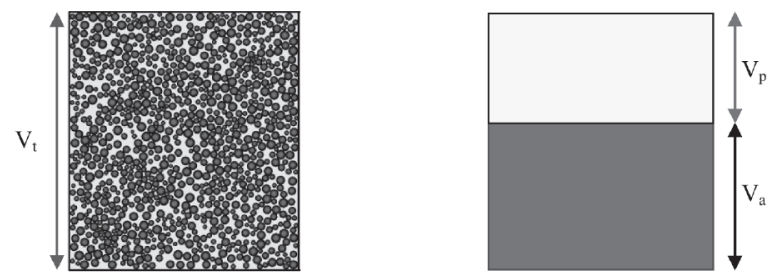

(a) Real system
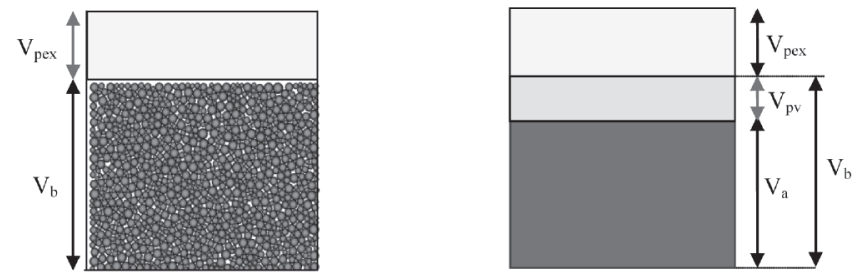

(b) Intermediate system

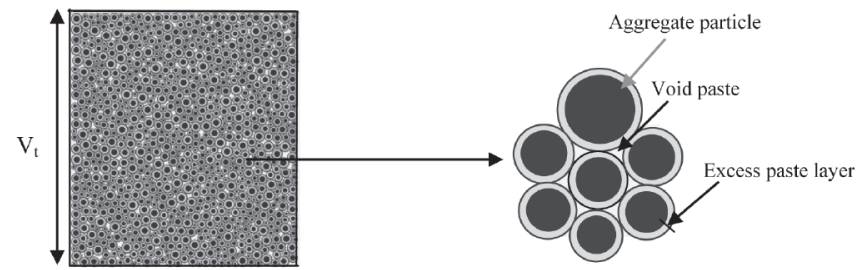

(c) Equivalent system

Figure 1. Two-phase aggregate-paste model for concrete. $V_{p}, V_{a}, V_{b}, V_{p}, V_{p v}$ and $V_{p e x}$ are volume of the sample, specific volume of the aggregate, bulk volume of the aggregate in compacted state, total paste volume, void paste volume and excess paste volume, respectively.

1. ábra Beton kétfázisú adalékanyag-pép modellje. $V_{p}, V_{a}, V_{b}, V_{p}, V_{p v}$ és $V_{p e x}$ a minta térfogata, az adalékanyag térfogata, az adalékanyag tömör térfogata, a teljes péptérfogat, a hézag péptérfogat és a többlet péptérfogat.

The paste phase is divided into two parts, i.e. the void paste and the excess paste (see Fig. 1.b). Void paste is used to fill the void space between the aggregate particles when they are in the compacted state. Void paste behaves like glue and tries to keep the aggregate particles in their positions. The volume of the void paste $\left(\mathrm{V}_{\mathrm{pv}}\right)$ is calculated with Eq. (3) [7]:

$\mathrm{V}_{\mathrm{pv}}=\left(\begin{array}{l}1 \\ \varsigma\end{array}-1\right) \mathrm{V}_{\mathrm{a}}$
Excess paste is used to form a paste layer with a constant thickness around every single aggregate particle (see Fig. 1.c). Excess paste layers try to facilitate the mobility of the aggregate particles. The volume of the excess paste $\left(\mathrm{V}_{\text {pex }}\right)$ can be calculated with Eq. (4).

$\mathrm{V}_{\mathrm{pex}}=\mathrm{V}_{\mathrm{p}}-\mathrm{V}_{\mathrm{pv}}$

where $V_{p}$ is the total volume of the paste in the system. The workability of a mixture is strongly correlated with two parameters, i.e. the consistency of the paste and the volume of the excess paste [7]. With increasing paste consistency and excess paste volume, an increase in workability would be expected for a given mixture [7].

\section{Workability assessment}

As there is no direct test method for the evaluation of workability, this property is indicated indirectly by measuring other performance parameters that are considered to be correlated somehow to the behaviour that must be controlled [11]. Focus is on the shape holding ability of fresh mixtures in this study. In order to evaluate the shape holding ability of mixtures, a slump test is performed [7]. The cone used in this study is selected according to EN 12350-5 [12]. Shape holding ability of mixtures is characterized by the shape preservation factor, $0<\mathrm{SPF} \leq 1$. SPF shows the ability of a mixture to preserve its shape after demolding. SPF is defined as the ratio of the vertical cross sectional area of a three dimensional (3D) sample after and before demolding, i.e. $A_{f} / A_{o}$ (see Fig. 2). SPF is equal to 1 for a mixture with zero flowability, i.e. no-slump concrete (NSLC). With increasing flowability of mixtures SPF gradually decreases [7].

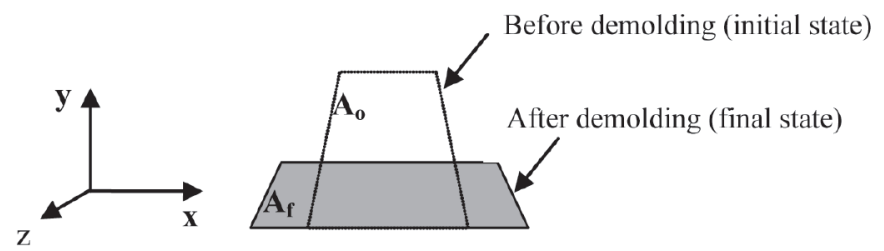

Figure 2. The vertical cross section of a three dimensional (3D) sample before and after demolding. $A_{o}$ and $A_{f}$ are the vertical cross sectional area of a $3 D$ sample before and after demolding, respectively. For a $3 D$ sample $A_{f} \leq A_{0}$.

2. ábra A 3 dimenziós minta függőleges metszete kizsaluzást megelözően. $A_{o}$ és $A_{f}$ a 3 dimenziós minta függöleges metszetének területe kizsaluzás elött és után. Egy 3 dimenziós minta esetén $A_{f} \leq A_{o}$.

\section{Materials and mix composition}

Aggregates used in this study consist of natural aggregate particles. The characteristics of the aggregates are given in Table 1.The packing density of aggregates is determined according to ASTM C29-1997 [13]. The paste phase consists of Portland cement CEM I 52.5 with specific density of 3.15 $\mathrm{g} / \mathrm{cm}^{3}$, limestone powder with specific density of $2.64 \mathrm{~g} / \mathrm{cm}^{3}$, water and superplasticizer. Three different combinations of water-cement ratio, $\mathrm{W} / \mathrm{C}$ and water-powder ratio, $\mathrm{W} / \mathrm{P}$ are considered for the pastes (see Fig. 3). 


\section{Characteristics}

Well graded aggregates with specific density of $2.56 \mathrm{~g} / \mathrm{cm}^{3}$, maximum size of $8 \mathrm{~mm}$, minimum size of $0.125 \mathrm{~mm}$ and packing density of about $0.80 \pm 0.2$.

Aggregate particles with a shape deviation of about 3\% from the spherical shape. Shape deviation determines the minimum interparticle distance at which particles become in direct contact [7].

Fineness modulus of granular material is kept between 3.5 and 5.0 to avoid 1) the effect of the gravitational forces acting on aggregate particles [ 7,14$]$ and 2) the effect of the very fine aggregate particles, i.e. the aggregate particles which are in the size range of the large powder particles $[7,14]$, on deformability of the mixtures.

Table 1. Characteristics of the aggregates.

1. táblázat Azadalékanyag jellemzói.

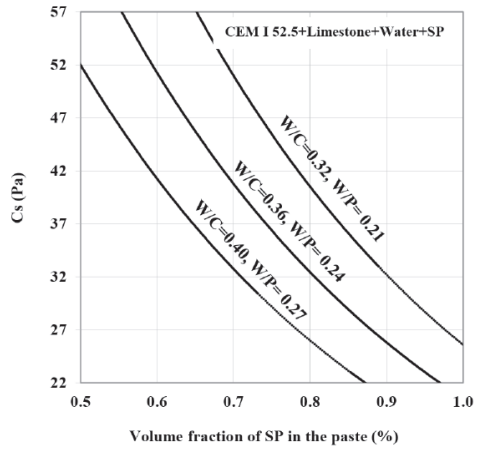

Fig. 3. Critical (yield) stress of the paste vs. volume fraction of superplacticizer SP in the paste for different combinations of water-cement ratio W/C and waterpowder ratio W/P. Higher critical stress implies lower consistency (lower ability to flow).

3. ábra Kritikus (folyási) feszültség a pép - folyósitószer (SP) térfogatarányára vonatkoztatva, különböző víz-cement tényezö, W/C és víz-kötőanyag tényezö, W/P kombinációk esetén. Nagyobb kritikus feszültséghez kisebb konzisztencia (kisebb folyási képesség) tartozik.

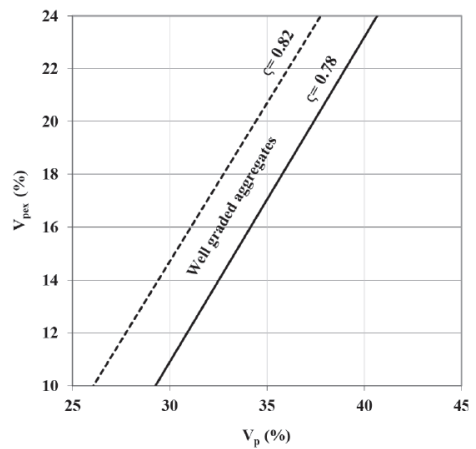

Fig. 4. Correlation between the volume fraction of excess paste $V_{\text {pex }}$ and the volume fraction of total paste $V_{p}$ in the mixtures made with a well graded aggregate. In this figure $c$ represents the packing density of the aggregates.

4. ábra Korreláció a többlet péptérfogat, $V_{\text {pex }}$ és a teljes péptérfogat, $V_{p}$ között, folytonos szemeloszlású adalékanyag esetén. Az ábrán ৎ az adalékanyag halmaztömörségét jelenti.

The consistency of the paste, which is controlled by the amount of superplasticizer (see Fig. 3), is characterized by the critical (yield) stress of the paste Cs [7]. A higher critical stress implies lower consistency (lower ability to flow). The excess paste volume fraction $\mathrm{V}_{\text {pex }}$ varies from $10 \%$ to $24 \%$ (the maximum volume fraction of the excess paste, which is usually recommended for a concrete mixture, is about $24 \%$ [6]). The correlation between the volume fraction of excess paste $\mathrm{V}_{\text {pex }}$ and the volume fraction of total paste $\mathrm{V}_{\mathrm{p}}$ in the mixtures is represented in Fig. 4.

\section{Results and discussion}

Correlation between the mix composition, which is characterized by the volume fraction of the excess paste $V_{\text {pex }}$ and critical (yield) stress of the paste Cs, and shape holding ability of mixtures is presented in Fig. 5. With increasing volume fraction of the excess paste and decreasing critical stress of the paste, the relative slump $\mathrm{H}_{\mathrm{s}} / \mathrm{H}_{\mathrm{o}}$ increases and the shape preservation factor SPF decreases. The slump value $\mathrm{H}_{\mathrm{s}}$ is the height reduction of the sample after lifting the cone [7]. The slump value $\mathrm{H}_{\mathrm{s}}$ and shape preservation factor SPF are equal to zero and one, respectively, for the mixtures which show no deformation after demolding, i.e. no-slump concrete mixture (NSLC).
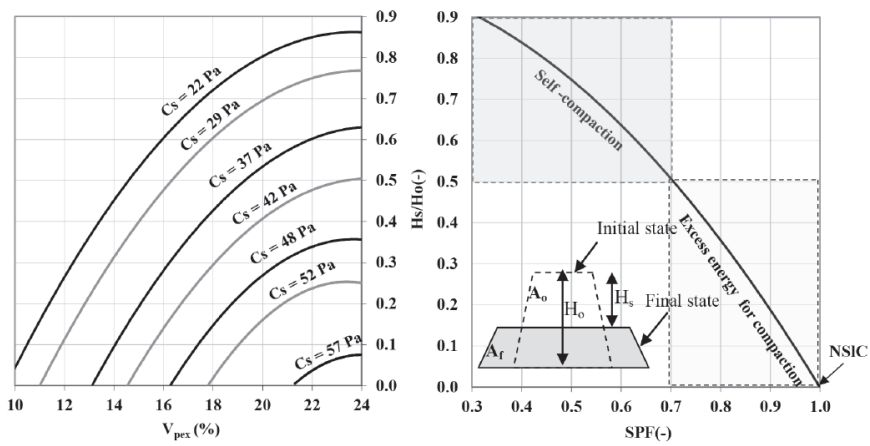

Figure 5. Correlation between the mix composition, which is characterized by the volume fraction of the excess paste $V_{\text {pex }}$ and critical (yield) stress of the paste $C s$, and shape preservation factor SPF. SPF is equal to the ratio of the vertical cross sectional area of a sample after and before demolding, i.e. $A / A_{0}$.

5. ábra Korreláció az összetételi jellemzök között; ennek paraméterei a többlet péptérfogat, $V_{\text {pex }}$ a pép kritikus (folyási) feszültsége, Cs, és az alaktényezö, SPF. Az alaktényezö, SPF a minta függöleges metszete területének arányát mutatja kizsaluzás elött és után, $=A / A_{0}$.

The maximum SPF for a self-compacting mixture is about 0.7 (see Fig. 5). For SPF $>0.7$, extra energy is required for proper compaction. A mixture with $\mathrm{SPF} \approx 0.7$ shows a relative slump $\mathrm{H}_{\mathrm{s}} / \mathrm{H}_{\mathrm{o}} \approx 0.5$ (see Fig. 5). For a mixture with $S P F \approx 0.7$, the spread diameter at final state $D_{f}$ is equal to $290 \mathrm{~mm} \pm 10 \mathrm{~mm}$ and thus the relative spread diameter $\mathrm{D}_{\mathrm{f}} / \mathrm{D}_{\mathrm{o}} \approx 1.4-1.5$ [7]. $\mathrm{H}_{\mathrm{s}} / \mathrm{H}_{\mathrm{o}} \approx 0.5$ and $\mathrm{D}_{\mathrm{f}} / \mathrm{D}_{\mathrm{o}} \approx 1.4-1.5$ are in the range of those proposed by Wang et al [5] for self-compacting mixtures used in pavement construction. They stated that those mixtures can preserve their shape without any additional support after the slip form paving process. For a conventional self-compacting concrete mixture (SCC) with a relative spread diameter $\mathrm{D}_{\mathrm{f}} / \mathrm{D}_{0} \geq 3$, the SPF is less than about 0.4 [7].

A self-compacting no-slump concrete (SCNSLC) could be achieved if we were able to increase the critical stress of the paste Cs shortly after placing and before demolding. A selfcompacting mixture with $\mathrm{SPF} \approx 0.7$ would behave like a noslump concrete with $\mathrm{SPF} \approx 1$ after demolding if we were able to increase Cs after placing of the mixture as presented in Fig. 6. The required increase of $\mathrm{Cs}$ is about $17 \mathrm{~Pa}$. With decreasing the shape preservation factor SPF of the reference mixture the larger increase of Cs is required [7].

At early age, i.e. when the hydration effect is still negligible, the rheological behaviour of a paste strongly depends on the attractive van der Waals forces and the repulsive electrostatic forces between the powder particles $[15,16]$. With decreasing repulsive forces between the particles the flowability (consistency) of the paste decreases. The repulsive electrostatic 
forces between the powder particles strongly depend on the ion concentration in the liquid in which particles are dispersed [17]. Therefore, if we could change the ion concentration in the mixture after placing, we would be able to control the paste consistency, and thus the shape holding ability of the mixture. A consistency change of the paste shortly after placing can theoretically be obtained by adding smart particles to a mixture before placing. Smart particles are made of materials with properties engineered to undergo changes in a controlled manner $[18,19]$. A smart particle usually consists of a core (fill) coated with a layer called membrane. The core contains a material that is released by breaking or dissolving the membrane under particular conditions. The inside content can be a latex material, i.e. a dispersion of charged particles [20]. The membrane can be made of a material which is engineered to dissolve in water in a controlled manner. This topic is beyond the scope of this paper. Further research is recommended.
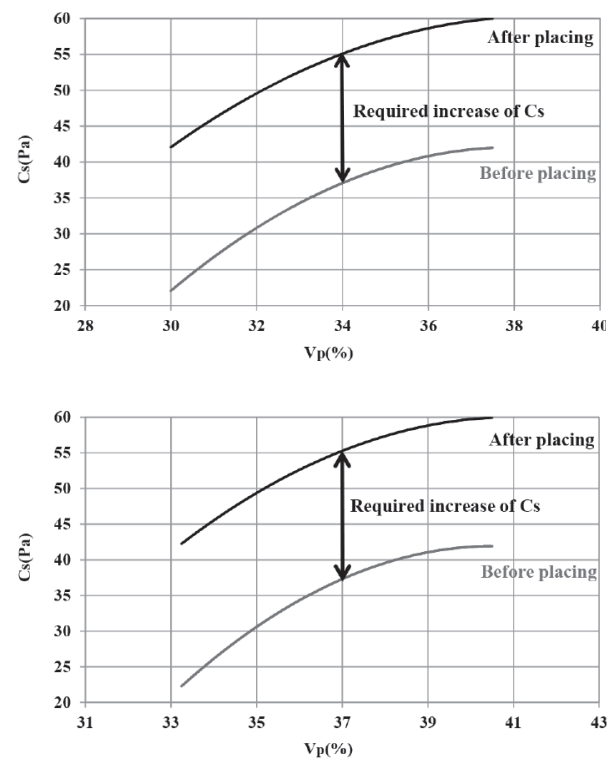

Figure 6. Required change of critical stress Cs of the paste for mixtures with shape preservation factor $S P F \approx 0.7$ to behave like a no-slump concrete after demolding. $V_{p}$ is the volume fraction of the total paste.

6. ábra A kritikus feszültség, Cs szükséges értéke a roskadásmentes beton eléréséhez az alaktényezö $S P F \approx 0.7$ értéke esetén; $V_{p}$ a teljes péptérfogat.

\section{Conclusions}

The objective of this paper was to study the possibility of developing a self-compacting no-slump concrete mixture (SCNSLC), i.e. a concrete mixture which can compact under its own weight while preserving its shape almost completely right after placing. In order to evaluate the shape holding ability of mixtures, slump test was performed. The shape holding ability of a mixture is indicated with the shape preservation factor $(0<\mathrm{SPF} \leq 1)$. SPF is defined as the ratio of the vertical cross sectional area of a three dimensional (3D) sample after and before demolding. For a no-slump concrete mixture (NSLC), i.e. a mixture with zero deformation after demolding, it holds SPF $=1$. It was found that the maximum SPF for a selfcompacting mixture is about 0.7 . For a self-compacting mixture with a higher shape preservation factor, i.e. SPF $>0.7$, especially SCNSLC, it is required to increase critical stress of the paste
Cs shortly after placing and before demolding. A consistency change of the paste shortly after placing can theoretically be obtained by, for example, adding smart particles to the mixture before placing. Further research on this topic is recommended.

\section{References}

[1] Neville, A. M. (1995): Properties of Concrete 4th Ed. Pearson Education Limited, England.

[2] Schindler, A. K. (2004): Prediction of concrete setting. Proc. Int. RILEM Symp. on Concrete Science and Engineering: A Tribute to Arnon Bentur. RILEM Publications SARL.

[3] Koehler, E. P. - Fowler, D. W. (2003): Summary of Concrete Workability Test Methods. International Center for Aggregates Research, The University of Texas, USA.

[4] ACI Committee 211.3R (2002): Guide for Selecting Proportions for NoSlump Concrete.

[5] Wang, K. et al (2011): Self-Consolidating Concrete-Applications for Slip-Form Paving: Phase II. National Concrete Pavement Technology Center, Institute for Transportation, Iowa State University, USA.

[6] RILEM TC 174 SCC (2000): Self-Compacting Concrete. RILEM Publications SARL.

[7] Hoornahad, H. (2014): Toward Development of Self-Compacting Noslump Concrete Mixtures - PhD Thesis. Ipskamp Drukkers BV.,Delft.

[8] EFNARC (2002): Specification and Guidelines for Self-Compacting Concrete.

[9] Kwan, A. K. H. - Mora, C. F. (2001): Effects of various shape parameters on packing of aggregate particles. Magazine of Concrete Research, Vol. 53, No. 2, pp. 91-100. http://dx.doi.org/10.1680/macr.53.2.91.39505

[10] Hu, C. - De Larrard, F. (1996): The rheology of fresh high performance concrete. Cement and Concrete Research. Vol. 26, No. 2, pp. 283-294. . http://dx.doi.org/10.1016/0008-8846(95)00213-8

[11] Wong, G. S. et al (2001): Portland-Cement Concrete Rheology and Workability: Final Report. USAE Research and Development Center.

[12] EN 12350-5 Testing Fresh Concrete - Part 5: Flow Table Test.

[13] ASTM C29/C29M (1997): Standard Test Method for Bulk Density (“Unit Weight") and Voids in Aggregate.

[14] Hoornahad, H. - Koenders, E. A. B. (2011): Consistency assessment method for granular-cement paste systems. Advanced Materials Research, Vols. 295-297, pp. 2178-2184. http://dx.doi.org/10.4028/www.scientific.net/AMR.295-297.2178

[15] Chappuis, J. (1982): Concrete Rheology. Materials Research Society, p. 38.

[16] Chappuis, J. (1986): Proceedings of the 8th International Congress on Chemistry of Cement. Vol. 6, p. 544.

[17] Coussot, P. (2005): Rheometry of Pastes, Suspensions,and Granular Materials. John Wiley \& Sons, New Jersey.

[18] Nayak, S. - Lyon, L. A. (2004): Photoinduced phase transitions in poly (n-isopropylacrylamide) microgels. Chemistry of Materials. Vol. 16, pp. 2623-2627. http://dx.doi.org/10.1021/cm049650i

[19] Ballauff, M. - Lu, Y. (2007): Smart nanoparticles: preparation, characterization, and applications. Polymer. Vol. 48, No. 7, pp. 1815-1823. http://dx.doi.org/10.1016/j.polymer.2007.02.004

[20] Rixom, R. - Mailvaganam, N. (1999): Chemical Admixtures for Concrete. E \& FN Spon, London.

Ref.:

Hoornahad, Hooman - Koenders, Eduardus A. B. - van Breugel, Klaas: Towards the development of self-compacting no-slump concrete mixtures Építőanyag - Journal of Silicate Based and Composite Materials, Vol. 67, No. 4 (2015), 135-138. p. http://dx.doi.org/10.14382/epitoanyag-jsbcm.2015.22 